Article

\title{
Serum Zinc Status During Different Trimesters of Gestation
}

\author{
Nushrat Noor ${ }^{1}$, Nasim Jahan², Nayma Sultana ${ }^{3}$, Rezina Akter ${ }^{4}$
}

\begin{abstract}
Background: Hypozincemia may be found in different trimesters of pregnancy. Gradual alteration of this micronutrient status during pregnancy is associated with increased maternal and infant mortality and morbidity. Objective: To measure serum zinc level of pregnant women in different trimesters in order to find out their micronutrient status. Method: This cross sectional study was carried out in the Department of Physiology, Sir Salimullah Medical College, Dhaka between $1^{\text {st }}$ January 2010 to $31^{\text {st }}$ December 2010. 90 normal pregnant women, age ranged from 20 to 30 years were included in the study group (Group-B) which was further divided into group $B_{1}$ consisting of 30 different pregnant women in $1^{\text {st }}$ trimester, group $\mathrm{B}_{2}$ consisting of 30 different pregnant women in $2^{\text {nd }}$ trimester and group $\mathrm{B}_{3}$ consisting of 30 different pregnant women in $3^{\text {rd }}$ trimester. Age matched 30 apparently healthy nonpregnant women (Group A) were also selected by for comparison. Serum zinc level was measured by Spectrophotometric method and serum total protein and albumin levels were estimated by standard laboratory technique. Statistical analysis was done by using ANOVA \& Spearman rank Correlation as applicable. Result: In this study, serum Zn level was significantly lower in $1^{\text {st }}(\mathrm{p}<0.01), 2^{\text {nd }}$ and $3^{\text {rd }}$ trimester $(\mathrm{p}<0.001)$ of pregnant women in comparison to that of non-pregnant women. Again, this value was significantly $(\mathrm{p}<0.001)$ lower in $3^{\text {rd }}$ trimester than those of $1^{\text {st }}$ and $2^{\text {nd }}$ trimesters of pregnant women. Moreover, serum Zn concentration showed negative correlation $(\mathrm{r}=-0.621)$ with different trimesters of gestation and this correlation was statistically significant $(\mathrm{p}<0.001)$. Conclusion: This study reveals that gradual hypozincemia was observed in pregnant women from $1^{\text {st }}$ to $3^{\text {rd }}$ trimester of gestation.
\end{abstract}

Key words: Serum zinc, Trimester, Pregnancy.

J Bangladesh Soc Physiol. 2011 June; 6(1): 52-57 For author affiliations, see end of text.

http://www.banglajol.info/index.php/JBSP

$\mathbf{P}$ cells and decreased concentrations of plasma proteins and micronutrients. In many developing countries, these changes can be aggravated by under nutrition which has fatal consequences for both mother and newborn infants ${ }^{1}$.Different researchers demonstrated that micro and macro nutrients are essential for the development of fetus. In pregnancy many minerals like zinc, copper, calcium and magnesium are transferred from mother to the fetus ${ }^{2}$.

52
Zinc (Zn) is an essential micronutrient required during different trimesters of pregnancy for fetal development and growth ${ }^{3,4}$ and its deficiency may affect pregnancy, delivery and outcome of pregnancy ${ }^{5}$. Zinc is essential for normal cellular growth and differentiation ${ }^{6}$ and has an important role in the development of nervous system ${ }^{7}$. This trace element plays an important role in various functions such as immunity, wound healing, growth, reproduction ${ }^{8}$, protein synthesis and nucleic acid metabolism ${ }^{9}$. The recommended daily allowance of $\mathrm{Zn}$ is $15 \mathrm{mg}$ during pregnancy and

J Bangladesh Soc Physiol. 2011 June; 6(1): 52-57 
$19 \mathrm{mg}$ during the lactation period ${ }^{10}$. Plasma zinc concentration begins to decline in early pregnancy and continues till term, which is about $35 \%$ below the concentration found in non pregnant women ${ }^{11}$.

It has been observed that serum zinc level was significantly lower during the first and second trimester of pregnancy as compared to non pregnant controls. But this micronutrient level was increased in the third trimester in comparison to that of first and second trimester ${ }^{12}$. Some other group of investigators also reported that serum zinc concentration was significantly higher in non pregnant women than that of pregnant women in all stages of gestation. They also observed that serum zinc concentration in pregnant women decreased gradually from the first to the third trimester of pregnancy ${ }^{13}$. Recently similar type of observation has also been reported by some other researchers ${ }^{14}$.

Micronutrient deficiency in women of reproductive age is recognized as a major public health problem in our country. Maternal under nutrition may predispose a mother to poor health and adverse pregnancy outcomes. Although some work on maternal serum zinc status and fetal outcome ${ }^{15}$ and role of zinc on preterm delivery ${ }^{16}$ were done in our country, but little is known about serum zinc level in different trimesters of gestation in healthy women. Therefore, the present study has been undertaken to estimate serum zinc concentration in different trimesters of gestation in apparently healthy women. It is expected that findings of this study would give a guideline to the obstetrician for better management of the pregnant women which may prevent maternal and fetal morbidity and mortality and reduce the risk of complication during and after the delivery.

\section{Methods}

This cross sectional study was carried out in the Department of Physiology, Sir Salimullah Medical College, Dhaka between $1^{\text {st }}$ January 2010 to $31^{\text {st }}$

J Bangladesh Soc Physiol. 2011 June; 6(1): 52-57
December 2010. A total number of 120 subjects were taken in this study, and all of them belonged to lower socioeconomic status. Among them 90 normal pregnant women, age ranged from 20 to 30 years were included in the study group (Group-B) which was further divided into group $B_{1}$ consisting of 30 different pregnant women in $1^{\text {st }}$ trimester, group $\mathrm{B}_{2}$ consisting of 30 different pregnant women in $2^{\text {nd }}$ trimester and group $\mathrm{B}_{3}$ consisting of 30 pregnant women in $3^{\text {rd }}$ trimester. Age matched 30 apparently healthy non-pregnant women (Group A) were also taken for comparison. Protocol of this study was approved by the Institutional Eithics Committee (IEC) of Sir Salimullah Medical College, Dhaka. All the pregnant women were collected from Out Patient Department (OPD) of Gynaecology and Obstetrics of Sir Salimullah Medical College and Mitford Hospital and non-pregnant were selected from personal contact. Subjects having history of any microbial and metabolic diseases, eclampsia/preeclampsia, smokers, tobacco/alcohol users, drug abusers and using prescribed medicine were excluded from this study. After selection of the subjects, the objectives and benefits of the study were explained to each subject and written informed consents were taken from the subjects. Detail personal, dietary, medical, family, socioeconomic, occupational and drug history of each subject were recorded in a prefixed questionnaire and thorough physical examinations were also done and documented. Height and weight of the subjects were measured for the calculation of BMI. With all aseptic precautions, $5 \mathrm{ml}$ of venous blood was drawn from median cubital vein by disposable syringe. Then blood sample was drawn directly into the deionized test tube. The whole blood was centrifuged at $3000 \mathrm{rpm}$ for 25 minutes. After that supernatant serum was collected in labeled eppendroff tube and from it $1 \mathrm{ml}$ of serum was taken in plain glass test tube for estimation of serum total protein and albumin by standard laboratory technique ${ }^{17}$ in the Department of Physiology, SSMC, Dhaka. Another $1 \mathrm{ml}$ was taken in de- ionized eppendroff tube for estimation of 
serum Zn level by Atomic Absorption Spectrophotometric method ${ }^{18}$ in the laboratory of Biochemistry Department of Bangabandhu Sheikh Mujib Medical University (BSMMU). The statistical analysis was done by One- way ANOVA(Post Hoc), Bonferroni and Spearman's rank correlation test by using SPSS, version- 16.

\section{Result}

All the groups were matched for age. But the mean BMI was significantly $(\mathrm{p}<0.001)$ higher in group $B_{1}, B_{2}$ and $B_{3}$ than that of group $A$ and also in $B_{3}$ than that of $B_{1}$. Again no significant difference of this value was observed between group $\mathrm{B}_{1}$ vs $\mathrm{B}_{2}$ and $\mathrm{B}_{2} \mathrm{vsB}_{3}$ (Table I).

Table I: Mean \pm SD of Age and Body Mass Index (BMI) in different groups $(\mathrm{n}=120)$

\begin{tabular}{cccc}
\hline Groups & $\mathrm{n}$ & Age(years) & $\mathrm{BMI}\left(\mathrm{kg} / \mathrm{m}^{2}\right)$ \\
\hline $\mathrm{A}$ & 30 & $25.43 \pm 3.24$ & $23.94 \pm 1.15$ \\
$\mathrm{~B}_{1}$ & 30 & $24.60 \pm 3.11$ & $27.72 \pm 3.27$ \\
$\mathrm{~B}_{2}$ & 30 & $24.43 \pm 3.32$ & $29.11 \pm 2.75$ \\
$\mathrm{~B}_{3}$ & 30 & $24.63 \pm 3.52$ & $30.82 \pm 2.54$ \\
\hline
\end{tabular}

Statistical analysis

\begin{tabular}{|c|c|c|}
\hline Groups & $\begin{array}{c}\text { Age } \\
\text { (p value) }\end{array}$ & $\begin{array}{c}\text { BMI } \\
\text { (p value) }\end{array}$ \\
\hline$A$ vs $B_{1}$ vs $B_{2}$ vs $B_{3}$ & $0.648^{\mathrm{ns}}$ & $0.000^{* * *}$ \\
\hline A vs $B_{1}$ & $0.999^{\text {ns }}$ & $0.000 * * *$ \\
\hline A vs $B_{2}$ & $0.999^{\text {ns }}$ & $0.000^{* * *}$ \\
\hline A vs $B_{3}$ & $0.999^{\text {ns }}$ & $0.000 * * *$ \\
\hline $\mathrm{B}_{1}$ vs $\mathrm{B}_{2}$ & $0.999^{\text {ns }}$ & $0.223^{\text {ns }}$ \\
\hline $\mathrm{B}_{1}$ vs $\mathrm{B}_{3}$ & $0.999^{\text {ns }}$ & $0.000 * * *$ \\
\hline $\mathrm{B}_{2}$ vs $\mathrm{B}_{3}$ & $0.999^{\text {ns }}$ & $0.064^{\mathrm{ns}}$ \\
\hline
\end{tabular}

Group A: Apparently healthy non pregnant (Control) Group $\mathrm{B}_{1}: 1^{\text {st }}$ trimester of gestation.

Group $\mathrm{B}_{2}: 2^{\text {nd }}$ trimester of gestation.

Group $\mathrm{B}_{3}: 3^{\text {rd }}$ trimester of gestation.

$* * *=$ Significant at $\mathrm{p}<0.001, \mathrm{~ns}=$ Not significant

54
The mean serum $\mathrm{Zn}$ level was significantly lower in group $\mathrm{B}_{1}(\mathrm{p}<0.01), \mathrm{B}_{2}(\mathrm{p}<0.001)$ and $\mathrm{B}_{3}(\mathrm{p}<$ 0.001 ) in comparison to that of group A. Again, this value was significantly $(p<0.001)$ lower in group $B_{3}$ than those of group $B_{1}$ and $B_{2}$. Similarly this value was lower in group $B_{2}$ in comparison to that of group $\mathrm{B}_{1}$, but the difference was not statistically significant (Figure 1).

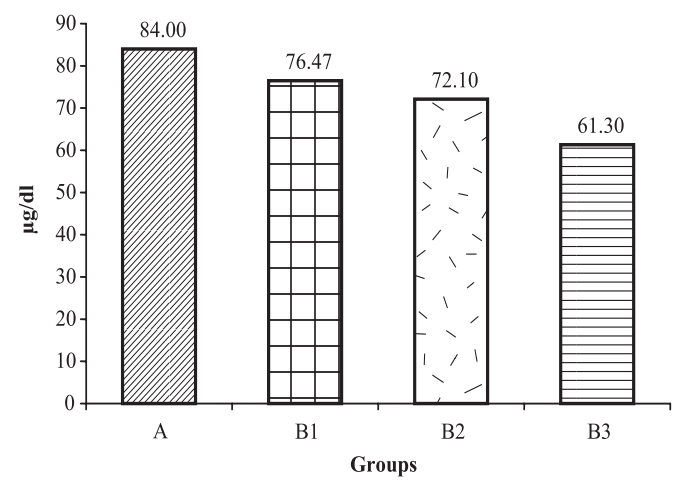

Figure 1: Mean Serum Zinc concentration in different groups $(\mathrm{n}=120)$

The mean serum total protein level was significantly $(\mathrm{p}<0.01)$ lower in group $\mathrm{B}_{3}$ than that of group $\mathrm{A}$. Whereas, this level was almost similar and showed no statistically significant differences among the other groups. Again, mean serum albumin level was significantly lower in group $\mathrm{B}_{2}$ and $\mathrm{B}_{3}$ than that of group $\mathrm{A}(\mathrm{p}<$ $0.001)$ and also of group $B_{1}(p<0.05)$. Whereas mean serum globulin level was almost similar and showed no statistically significant difference among the groups. On the other hand, $A / G$ ratio was significantly $(p<0.05)$ lower only in group $\mathrm{B}_{2}$ in comparison to that of group $\mathrm{A}$ (Table II).

Again, serum Zn concentration was negatively correlated ( $r=-0.621)$ with different trimesters of gestation and this relationship was statistically significant $(\mathrm{p}<0.001)$ (Figure 2).

J Bangladesh Soc Physiol. 2011 June; 6(1): 52-57 
Serum Zinc Status During Different Trimesters of Gestation

Article

Table II: Mean \pm SD of Serum Total Protein, Albumin, Globulin levels and A/G ratio in different groups ( $\mathrm{n}=120)$

\begin{tabular}{lccccc}
\hline Groups & $\mathrm{n}$ & Total Protein $(\mathrm{g} / \mathrm{dl})$ & Albumin $(\mathrm{g} / \mathrm{dl})$ & Globulin $(\mathrm{g} / \mathrm{dl})$ & $\mathrm{A} / \mathrm{G}$ ratio \\
\hline $\mathrm{A}$ & 30 & $6.92 \pm 0.98$ & $4.30 \pm 0.71$ & $2.61 \pm 0.88$ & $1.89 \pm 0.90$ \\
$\mathrm{~B}_{1}$ & 30 & $6.61 \pm 1.00$ & $3.97 \pm 0.64$ & $2.64 \pm 0.75$ & $1.64 \pm 0.64$ \\
$\mathrm{~B}_{2}$ & 30 & $6.31 \pm 1.02$ & $3.53 \pm 0.53$ & $2.78 \pm 0.77$ & $1.38 \pm 0.52$ \\
$\mathrm{~B}_{3}$ & 30 & $6.01 \pm 0.94$ & $3.53 \pm 0.54$ & $2.49 \pm 0.70$ & $1.52 \pm 0.47$ \\
\hline
\end{tabular}

Statistical analysis

\begin{tabular}{|c|c|c|c|c|}
\hline Groups & $\begin{array}{c}\text { Total Protein } \\
\text { (p value) }\end{array}$ & $\begin{array}{l}\text { Albumin } \\
\text { (p value) }\end{array}$ & $\begin{array}{l}\text { Globulin } \\
\text { (p value) }\end{array}$ & $\begin{array}{l}\text { A/G ratio } \\
\text { (p value) }\end{array}$ \\
\hline A vs B1vsB2 vs B3 & $0.004 * *$ & $0.000 * * *$ & $0.553^{\mathrm{ns}}$ & $0.023^{*}$ \\
\hline$A$ vs $B_{1}$ & $0.999^{n s}$ & $0.230^{\text {ns }}$ & $0.999^{\text {ns }}$ & $0.843^{\mathrm{ns}}$ \\
\hline$A$ vs $B_{2}$ & $0.111^{\mathrm{ns}}$ & $0.000 * * *$ & $0.999^{\text {ns }}$ & $0.018^{*}$ \\
\hline$A$ vs $B_{3}$ & $0.003 * *$ & $0.000 * * *$ & $0.999^{\text {ns }}$ & $0.182^{\text {ns }}$ \\
\hline $\mathrm{B}_{1}$ vs $\mathrm{B}_{2}$ & $0.999^{\text {ns }}$ & $0.037 *$ & $0.999^{\mathrm{ns}}$ & $0.736^{\mathrm{ns}}$ \\
\hline$B_{1}$ vs $B_{3}^{2}$ & $0.123^{\mathrm{ns}}$ & $0.032 *$ & $0.999^{n s}$ & $0.999^{\mathrm{ns}}$ \\
\hline $\mathrm{B}_{2}$ vs $\mathrm{B}_{3}$ & $0.999^{n s}$ & $0.999^{\text {ns }}$ & $0.907^{\mathrm{ns}}$ & $0.999^{\text {ns }}$ \\
\hline
\end{tabular}

*** Significant at $\mathrm{p}<0.001$, ** Significant at $\mathrm{p}<0.01$, * Significant at $\mathrm{p}<0.05$, ns Not significant, $\mathrm{P}>0.05$

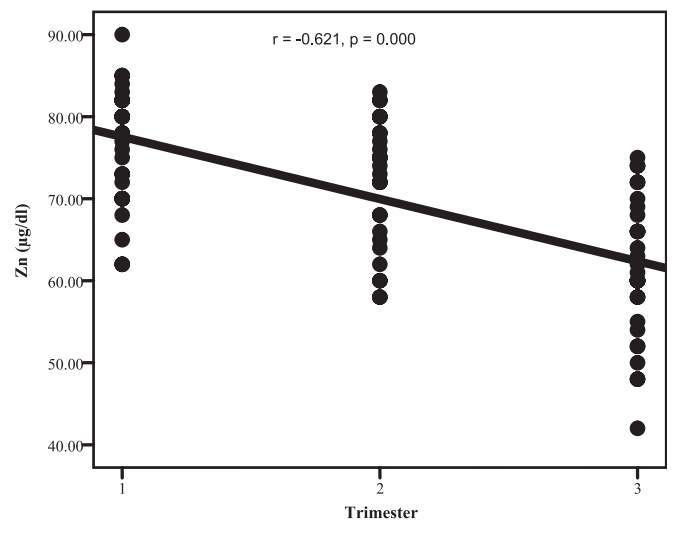

Figure 2: Correlation of Serum Zinc concentration with different trimesters of gestation $(n=90)$

\section{Discussion}

In this study, decreased serum $\mathrm{Zn}$ level has been found during different trimesters of pregnant women and maximum decreased value was observed in $3^{\text {rd }}$ trimester. This finding is in consistent with that of some other researchers ${ }^{19}$, 20. On the contrary, serum Zn level was also found higher in the $3^{\text {rd }}$ trimester in comparison to those of $1^{\text {st }}$ and $2^{\text {nd }}$ trimester of pregnant women $^{12}$. This discrepancy might be due to serum Zn level was measured near full term of pregnancy in that study. But in the present study this micronutrient level was measured within 32 weeks of gestation. Again, serum $\mathrm{Zn}$ concentration has shown significant $(p<0.001)$ negative correlation with different trimesters of gestation in present study. Similar observation is also made by other investigators ${ }^{21}$.

Some researchers suggested that decrease in serum albumin, albumin-bound zinc and á-2 macroglobulin-bound zinc contribute to low serum zinc level in pregnancy. The affinity of albumin for Zn of pregnant women is less than that of non-pregnant women, this may be the primary reason of hypozincaemia in pregnancy ${ }^{22}$. It has also been reported that poor nutritional status, low dietary intake and increased body demand during pregnancy may be responsible for lower level of serum $\mathrm{Zn}$ in different trimester of gestation ${ }^{21}$.

Moreover, it has also been suggested that increased urinary Zn excretion decreases serum 
Zn level during $1^{\text {st }}$ trimester may be due to increased glomerular filtration rate ${ }^{23}$ and decreased availability of $\mathrm{Zn}$ binding protein during pregnancy ${ }^{22}$. Again, lower level of serum $\mathrm{Zn}$ in $2^{\text {nd }}$ and $3^{\text {rd }}$ trimester may be due to $30-40 \%$ increase in blood volume and increased demand for the fetal development ${ }^{24}$. Again, serum Zn level become lower during $3^{\text {rd }}$ trimester may be due to several factors such as increased transfer of plasma Zn to maternal erythrocyte ${ }^{25}$ increased $\mathrm{Zn}$ uptake by the fetus and placenta ${ }^{21}$. In addition, high copper intake can decrease zinc absorption by competing at absorption sites causes hypozincemia in pregnancy ${ }^{26}$. Moreover, it has been suggested that excessive amount of iron and folate supplementation during $2^{\text {nd }}$ and $3^{\text {rd }}$ trimester causes reduction of plasma $\mathrm{Zn}$ concentration by inhibiting Zn absorption ${ }^{27}$. In the light of present accepted views, gradual decrease in serum zinc level in different trimesters of pregnancy may be due to haemodilution, decreased availability of zinc binding protein level, hormonal changes during pregnancy ${ }^{28}$ and active transport of zinc from mother to the fetus $^{29}$.

In the present study, a gradual decrease in serum zinc level was observed in pregnant women in different trimesters, which was more pronounced in third trimester This low serum Zn level in pregnant women of the present series are most likely due to decreased availability of binding protein as their measured value was lower. Furthermore, significant negative correlation of serum $\mathrm{Zn}$ level with different trimesters of gestation indicating the requirements of this micronutrient on each trimester of gestation which is more marked in $3^{\text {rd }}$ trimester.

\section{Conclusion}

From this study, it can be concluded that gradual hypozincemia was observed in pregnant women from $1^{\text {st }}$ to $3^{\text {rd }}$ trimester of gestation. Hypozincemia may be due to poor nutritional status during pregnancy as serum total protein and albumin levels were lower in this group of subjects. So, in pregnant women routine screening of serum zinc level during antenatal period is suggested which may reduce pregnancy related complication.

\section{Acknowledgement}

Authors of this study are thankful to the authority of Department of Biochemistry, BSMMU for the cooperation regarding laboratory facility they provided. The authors acknowledge the partial financial support from the research grant of DGHS of Bangladesh. The authors also thankful to all of study subjects for their active and cordial cooperation to carry out the study.

\section{Author Affiliations}

1. *Dr. Nushrat Noor, E-mail: noor.nushrat@gmail.com

2. Professor Nasim Jahan, Professor and Head, Department of Physiology, Sir Salimullah Medical College SSMC, Mitford, Dhaka. mail: prof.dr.nasimjahan@gmail.com

3. Nayma Sultana, Assistant Professor, Department of Physiology, Sir Salimullah Medical College SSMC, Mitford, Dhaka. E-mail: nayma_sultana@yahoo.com

4. Rezina Akter, Associate Professor, Department of Physiology, Sir Salimullah Medical College SSMC, Mitford, Dhaka. E-mail: akter.rezina@yahoo.com

* For correspondence

\section{References}

1. Ladipo OA. Nutrition in pregnancy: mineral and vitamin supplements. American Journal of clinical Nutrition. 2000; 72: 280-290.

2. Baig S, Hasnain NU, Uddin Q. Studies on $\mathrm{Zn}, \mathrm{Cu}$, $\mathrm{Mg}, \mathrm{Ca}$ and phosphorus in maternal and cord blood. Journal of Pakistan Medical Association. 2003; 53 (9): 417.

3. Black RE. Micronutrients in pregnancy. British Journal of Nutrition. 2001; 85 (2): 193-197.

4. Ashworth CJ, Antipatis C. Micronutrient programming of development throughout gestation. Reproduction. 2001; 122: 572-535.

5. Upadhyayan C, Mishra S, Ajmera P, Sharma P. Serum iron, copper and zinc status in maternal and cord blood. Indian Journal of Clinical Biochemistry. 2004; 19 (2): 48- 52.

6. Iannotti LL, Zavaleta N, Leon, Shankar AH, Caulfield LE. Maternal zinc supplementation and

J Bangladesh Soc Physiol. 2011 June; 6(1): 52-57 
growth in Peruvian infants. Am J Clin Nutr. 2008; 88: $154-160$.

7. Hurley LS. Teratogenic aspects of manganese, zinc and copper nutrition. Physiol Rev. 1981; 61: 249295.

8. Prasad AS. Zinc: an overview. International Journal. 1995; 11: 93.

9. Milne DB. Trace elements. In: Burtis CA, Ashwood ER, editor. Teitz Text Book of Clinical Chemistry. Philadelphia: WB Saunders Company; 2001. p. 1029-1056.

10. Krebs NF, Hambidge KM, Jacobs MA, Rasbach JO. The effect of a dietary zinc supplement during lactation on longitudinal changes in maternal zinc status and milk zinc concentrations. Am J Clin Nutr. 1985; 41: 560.

11. Zimmerman AW, Dunham BS, Nochimson DJ, Kaplan BM, Clivo JM, Kiokel SL. Zinc transport in pregnancy. Am J Obstet Gynecol. 1984; 149: 523-529.

12. Sharma R, Shinghal KC, Tewart K, Gupta M. Serum zinc levels in non pregnant and pregnant women. Indian J Pharmac. 1991; 23: 242-246.

13. Martin-Lagos F, Navarro-Alarcon M, TerresMartos C, Lopez-Garcia De La Serrana H, PerezValero V, Lopez-Martinez MC. Zinc and copper concentrations in serum from Spanish women during pregnancy. Biological Trace Element Research. 1998; 61: 61-70.

14. Alvarez SI, Castanon SG, Ruata MLC, Aragues EF, Terraz PB, Irazabal YG, Gonjalez EG, Rodriguez BG. Updating of normal levels of copper, zinc and selenium in serum of pregnant women. Journal of Trace Elements in Medicine and Biology. 2007; 21: 49-52.

15. Rahman H. Maternal zinc status and fetal outcome. [M. Phil thesis]. [Dhaka]: University of Dhaka; 2004.

16. Sultana M, Jahan N, Sultana N, Quraishi SB, Chowdhury TR, Khanum AA. Preterm delivery: Role of zinc. J Bangladesh Soc Physiol. 2010; 5(1): 27-33.

17. Weichselbaum TE. Am J Clin Path. 1946; 16: 40.
18. Smith JC, Butrimovitz GP, Purdy WC. Direct measurement of zinc and copper in plasma by Atomic Absorption Spectroscopy. Clin Chem. 1979; 25 (8): 1487-1491.

19. Al-Bader A, Hussain T, Al-Mosawi M, Otaibi M, Abul H, Khalifa, Dashti H. Serum zinc and copper concentrations in pregnant women from Kuwait. The Journal of Trace Elements in Experimental Medicine. 1997; 10: 209-215.

20. Awadallah SM, Abu-Elteen KH, Elkarmi AZ, Qaraein SH, Salem NM, Mubarak MS. Maternal and cord blood serum levels of zinc, copper, and iron in healthy pregnant Jordanian women. The journal of Trace Elements in Experimental medicine. 2004; 17: 1-8.

21. Jeswani RM, Vani SN. A study of serum zinc levels in cord blood of neonates and their mothers. Indian J Pediatr. 1991; 58: 683-687.

22. Giroux EL, Schechter PJ, Schoun J. Diminished albumin binding of zinc in serum of pregnant women. Clin Sci Mole Med. 1976; 51: 545-549.

23. Swanson CA, King CJ. Zinc and pregnancy outcome. Am J Clin Nutr. 1987; 46: 763-771.

24. McGanity WJ, Dawson EB, Fogekman A. Nutrition in pregnancy and lactation. In: Shils ME, Olson JA, Shike M, editors. Modern Nutrition in Health and Disease. Philadelphia: Lea and Febiger; 1994. p. 705-726.

25. Vir SC, Love AGG, Thompson W. Zinc concentration in hair and serum of pregnant women in Belfast. Am J Clin Nutr. 1981; 34: 2800-2807.

26. Sheldon WL, Aspillaga MO, Smith PA, Lind T. The effect of oral iron supplementation on zinc and magnesium levels during pregnancy. Br J Obstet Gynaecol. 1985; 92: 892-898.

27. O’Brien KO, Zavaleta N, Caulfield LE, Wen J, Abrams SA. Prenatal iron supplements impair zinc absorption in pregnant Peruvian women. J Nutr. 2000; 130: 2251-2255.

28. Jameson S. Effects of zinc deficiency in human reproduction. Acta Medica Scandinavica Supplementum. 1976; 593: 4-89.

29. Tamura T, Goldenberg RL. Zinc nutriture and pregnancy outcome. Nutrition Research. 1996; 16: 139-181. 